\title{
Pemanfaatan Jamur Trichoderma sp Sebagai Antagonis Patogen Busuk Sulur Tanaman Buah Naga Merah (Hylocereus polyrhizus) Secara In Vitro
}

\section{Utilization of Trichoderma sp fungus as a foul pathogen antagonist for red dragon fruit plant (Hylocereus polyrhizus) in vitro}

\author{
Herlyan Prasetiyo ${ }^{1}$, Purwati ${ }^{2}$, Iin Arsensi ${ }^{2}$ \\ Tenaga Pendidik Program Studi Agroteknologi, Fakultas Pertanian, Universitas Widya Gama Mahakam \\ Jl. KH. Wahid Hasyim, Sempaja, Samarinda, Kalimantan Timur \\ e-mail: lyanprase@gmail.com, purwatiuwgm@.com, iinarsensi@uwgm.ac.id
}

Diterima : 10 Mei 2018 Disetujui : 1 Juni 2018

\begin{abstract}
Utilization of Trichoderma sp fungi as pathogenic fungi antagonists in red dragon fruit plants (Hylocereus polyrhizus) in vitro. The purpose of this study was to identify foul pathogens of dragon fruit plants and then test the ability of Trichoderma sp antagonists to deciduous pathogens of red dragon fruit plants in vitro. The study was conducted from August to October 2016, The research was conducted at the Laboratory of Pest and Plant Disease Sciences, Faculty of Agriculture, Mulawarman University, Samarinda. Sampling of plants exposed to foul tendrils was carried out in Bukit Merdeka Village, Samboja District, Kutai Kartanegara Regency. There are two data observed in this study, primary data and secondary data. Primary data is data obtained directly from the source through direct field observations and laboratory observations and secondary data data obtained from interviews with farmers. The results showed that the pathogen that causes tendon rot in dragon fruit plants is the fungus Colletotrichum gloesporioides (penz. Ssaac). Trichoderma sp can inhibit the development of pathogens Colletotrichum gloesporioides (Penz.) Ssaac., With the highest average resistance of $71.85 \%$.
\end{abstract}

Keyword: Trichoderma sp, Pathogen, Red Dragon Fruit Plant

\section{PENDAHULUAN}

Tanaman buah naga yang berasal dari Amerika Tengah dan Selatan belum banyak dibudidayakan. Tanaman ini baru dibudidayakan secara intensif di beberapa negara seperti: Israel, Colombia, Nikaragua, Vietnam, Thailand, Cina, dan Australia (Lichtenzveig, dkk,. 2000). Buah naga dapat dikonsumsi dalam bentuk segar maupun olahan. Menurut Kristanto (2003), buah naga mempunyai kandungan air yang sangat tinggi sekitar 90,20\% dari berat buah. Rasanya cukup manis karena gula dalam buah yang cukup tinggi. Selain dibudidayakan sebagai tanaman buah, buah naga juga dibudidayakan sebagai tanaman obat karena memiliki khasiat untuk kesehatan manusia. Khasiat tersebut antara lain: sebagai penyeimbang gula darah, pencegah kanker usus, pelindung kesehatan mulut, menurunkan kolestrol, pencegah pendarahan, dan obat keluhan keputihan.

Tanaman ini mulai dikenal dan dibudidayakan di Indonesia pada tahun 2000. Meskipun demikian, perkembangan budidaya tanaman ini sangat lambat, padahal kondisi iklim Indonesia sangat mendukung untuk pengembangan tanaman ini. Pada tahun 2006 baru ada beberapa daerah yang membudidayakan tanaman ini yaitu Malang, Kediri, Tawangmangu, Semarang, dan Kulon Progo dengan luas pertanaman yang beragam. Beberapa tahun terakhir ini, setelah diketahui bahwa buah naga berkhasiat obat, usaha budidaya buah naga terus dilakukan karena sangat menguntungkan. Meskipun demikian, pembudidayaan buah naga kulit kuning masih jarang dilakukan, Buah naga yang dibudidayakan di Indonesia ada 2 genus yaitu Hylocereus dan selenicereus. Buah naga yang dibudidayakan adalah buah naga dari genus Hylocereus yaitu $H$. undatus (daging buah putih), $H$. polyrhizus (daging buah berwarna merah tua), dan $H$. costaricensis (daging buah berwarna merah muda) (Setyowati, 2008).

Tanaman buah naga kini mulai banyak dibudidayakan di Provinsi Kalimantan Timur, tepatnya di Kabupaten Kutai Kartanegara. Tanaman ini mulai masuk pertama kali di Kalimantan Timur yaitu berupa setek batang berukuran $20 \mathrm{~cm}$ yangdiambil dari Jawa Barat. Tanaman buah naga mulai dibudidayakan secara meluas di Kabupaten Kutai Kartanegara pada tahun 2009. Kini dari luas 671 ha pertanaman buah di Kabupaten KutaiKartanegara, $65 \%$ telah berproduksi (Dinas Pertanian Tanaman Pangan Kaltim, 2009). Desa Batuah Kecamatan 
Loa Janan merupakan salah satu produsen buah naga yang cukup tinggi yaitu $12,5 \mathrm{Mg}$ ha- 1 dari 14 ha pertanaman buah naga yang dikelola bersama gabungan kelompok tani (Dinas Pertanian Tanaman pangan Kaltim, 2014).

Pengembangan buah naga kini terhambat oleh masalah dalam budidaya serta OPT (Organisme Pengganggu Tanaman) terutama yang disebabkan oleh Patogen busuk batang pada tanaman buah naga. Patogen sering kali menjadi faktor pembatas dalam budidaya tanaman. 2 Secara umum, menurut Palungkun dan Indrayani (1992) kerusakan oleh OPT berpengaruh terhadap kualitas dan kuantitas hasil panen.

Pengendalian terhadap patogen tanaman saat ini masih bertumpu pada penggunaan pestisida sintetis. Namun penggunaan pestisida sintetik secara terus-menerus dapat menimbulkan berbagai macam dampak negatif. Suwahyono (2009), menyatakan bahwa penggunaan pestisida sintetik dapat membahayakan keselamatan hayati termasuk manusia dan keseimbangan ekosistem. Oleh sebab itu, saat ini metode pengendalian telah diarahkan pada pengendalian secara hayati.

Trichoderma diketahui memiliki kemampuan antagonis terhadap cendawan patogen. Trichoderma mudah ditemukan pada ekosistem tanah dan akar tanaman. Cendawan ini adalah mikroorganisme yang menguntungkan, avirulen terhadap tanaman inang, dan dapat memparasit cendawan lainnya (Harman dkk., 2004).

Serangan patogen busuk batang buah naga di sentra perkebunan buah naga Bukit Merdeka, Kecamatan Samboja, Kabupaten Kutai Kartanegara, kerusakan perkebunan buah naga mencapai ratusan hektar dan kerugian diperkirakan mencapai ratusan juta rupiah, dilaporkan upaya pengendalian penyakit tersebut dengan menggunakan pestisida tertentu belum dapat memperlihatkan hasil (anonim, 2016)a. Selain itu 436 hektar perkebunan buah naga di Kecamatan Samboja terserang penyakit busuk batang, diketahui sebelumnya ternyata serangan patogen busuk batang sudah terjadi sejak tahun 2014 silam, namun saat itu serangan penyakit busuk batang masih terjadi dalam skala kecil sehingga petani masih dapat memanen buah naga dalam kuantitas yang normal seperti tahuntahun sebelumnya. Beberapa instansi pemerintah terkait sudah ikut turun tangan untuk mengatasi permasalahan busuk batang buah naga ini, namun juga belum menemukan solusi tepat, salah satunya adalah UPTD Balai Proteksi Tanaman Pangan Holtikultura (TPH)
Kalimantan Timur, upaya yang sudah dilakukan adalah penggunaan agen hayati Trichoderma sp, namun belum juga dapat menekan perkembangan penyakit busuk batang buah naga (anonim, 2016)b. Berdasarkan uraian diatas perlu dilakukan penelitian mengenai efektifitas Trichoderma sp untuk menghambat pertumbuhan penyakit busuk batang buah naga secara in vitro.

\section{BAHAN DAN METODE}

Penelitian ini dilaksanakan \pm 2 bulan, yaitu dimulai pada Agustus - Oktober 2016. Lokasi pengambilan sampel di Desa Bukit Merdeka, Kecamatan Samboja, Kabupaten Kutai Kartanegara. Dilanjutkan identifikasi dan Uji Daya Hambat di Laboratorium Ilmu Hama Penyakit Tumbuhan, Fakultas Pertanian, Universitas Mulawarman, Samarinda. Bahan yang digunakan adalah bagian batang/sulur tanaman buah naga yang bergejala, media Potato Dekstrokse Agar (PDA), alkohol, Air destilasi, Cairan Methilen blue. Data yang diamati dalam penelitian ini ada dua yaitu, data primer dan data sekunder. Data primer adalah data yang diperoleh secara langsung dari sumbernya melalui pengamatan langsung lapangan dan pengamatan laboratorium, adapun parameter patogen yang diamati adalah Jamur. Metode dalam penelitian ini adalah metode survei. Penentuan sampel menggunakan metode Purposive sampling atau Judgmental sampling yaitu penarikan sampel secara purposive merupakan cara penarikan sampel yang memilih objek (sulur) yang dianggap terserang atau terdapat gejala serangan Patogen dan mengambil sampel tanah di lokasi penelitian, pengambilan sampel tanah menggunakan cangkul. Sedangkan pengambilan sampel sulur yang bergejala dengan cara memotong bagian tanaman yang terdapat gejala serangan patogen dimasukkan ke dalam kantong plastik dan dibawa ke Laboratorium. Pelaksanaan penelitian yaitu ; isolasi dan identifikasi jamur patogen busuk sulur tanaman buah naga, isolasi dan identifikasi jamur tanah spesifik lokasi trichoderma $s p$. dan uji antagonis trichoderma $s p$ terhadap pertumbuhan jamur patogen busuk sulur tanaman buah naga secara in vitro Parameter yang diamati adalah persentase daya hambat (\%) dari jamur trichoderma $s p$ terhadap patogen busuk sulur pada buah naga dengan menggunakan rumus (Supriati, dkk, 2010).

$$
\mathrm{P}=\frac{\mathrm{r} 1-\mathrm{r} 2}{\mathrm{r} 1} \times 100 \%
$$


Dimana :

$\mathrm{P}$ : Presentase penghambat

r1 : Jari-jari koloni pathogen yang berlawanan arah dengan cendawan antagonis

r1 : Jari-jari koloni pathogen yang menuju arah dengan cendawan antagonis

Rancangan perlakuan jamur Patogen diberi perlakuan kompetisi dengan Jamur Trichoderma $s p$ untuk uji antagonis sebanyak 5 ulangan.

\section{HASIL DAN PEMBAHASAN}

\section{Isolasi dan Identifikasi Jamur Patogen Pada Buah Naga}

Hasil pengamatan isolasi jamur patogen penyebab busuk sulur buah naga secara makroskopis terdapat miselium yang terdiri dari benang-benang hifa berwarna putih yang tersusun seperti bulu, dan setelah beberapa hari hifa berubah menjadi hitam, pengamatan secara visual dapat dilihat pada gambar 1 .

Hasil pengamatan mikroskopis dengan menggunakan mikroskop patogen penyebab penyakit buah naga adalah jamur patogen Colletotrichum gloeosporioides (Penz.) Sacc,berdasarkan pengamatan dengan menggunakan kunci determinasi menggunakan buku Barnett dan Hunter (1972) menunjukan adanya hifa dan konidia khas dari Colletotrichum gloeosporioides (Penz.) Sacc pengamatan secara mikroskopis dapat dilihat pada gambar 2 .

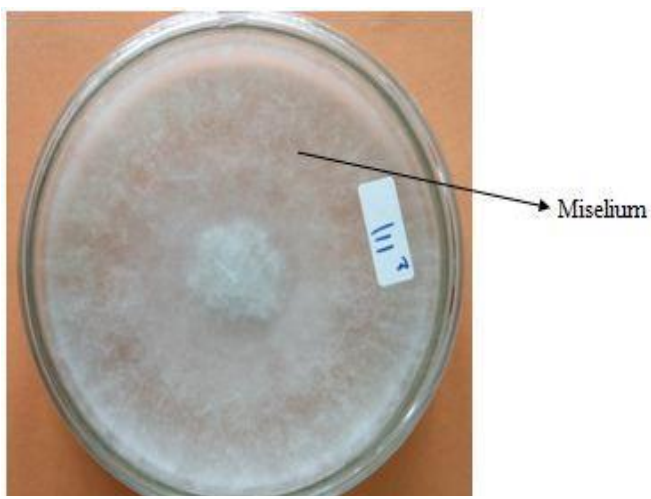

Gambar 1. Miselium Colletotrichum gloeosporioides (Penz.) Sacc

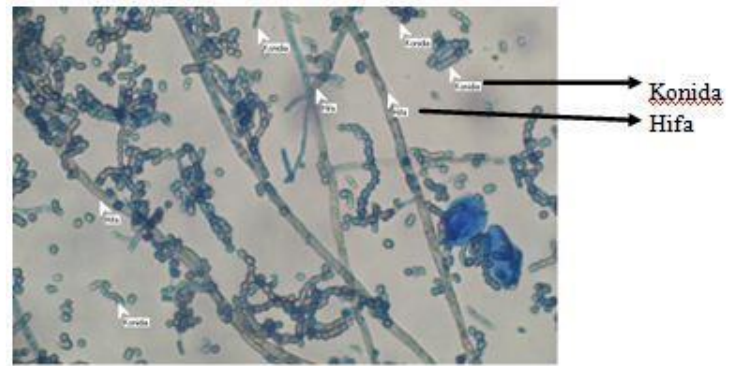

Gambar 2. Jamur Colletotrichum gloeosporioides (Penz.) Sacc

\section{Isolasi dan Identifikasi Jamur Tanah Spesifik} Lokasi Trichoderma

Hasil pengamatan isolasi jamur Trichoderma $s p$ secara visual dapat dilihat pada Gambar 3 dan 4.

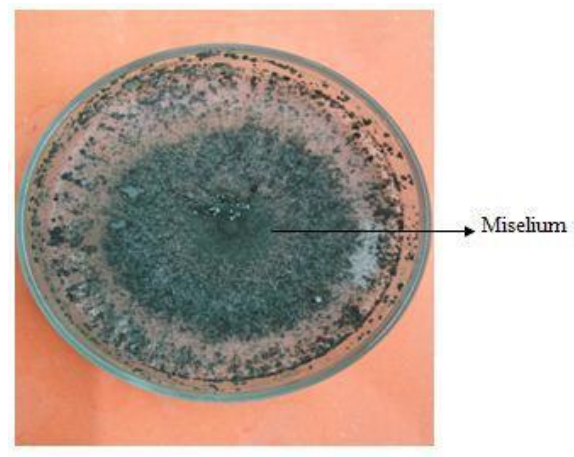

Gambar 3. Miselium Trichoderma sp

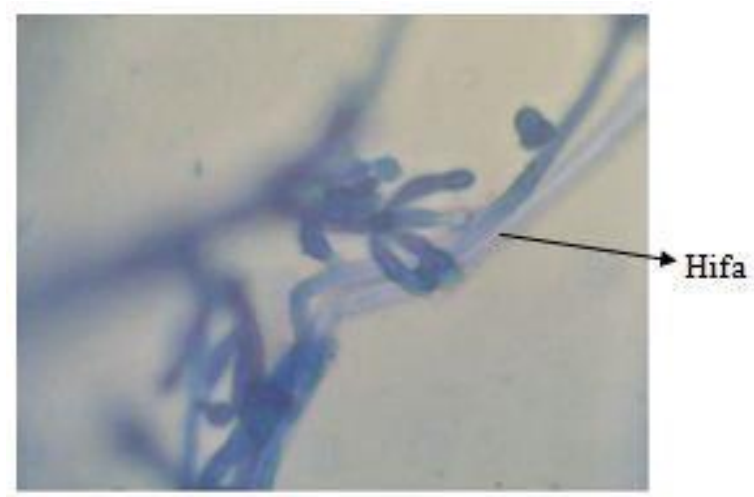

Gambar 4. Jamur Trichoderma sp

\section{Hasil Uji Antagonis Trichoderma Terhadap Colletotrichum gloeosporioides.}

Persentaase (\%) Hasil Uji Antagonis Trichoderma spterhadap Colletotrichum gloeosporioides dapat dilihat pada tabel 1. 
Tabel 1. Uji Daya Hambat jamur Trichoderma sp terhadap Colletotrichum gloeosporioides penyebab busuk sulur pada tanaman buah naga

\begin{tabular}{|l|c|c|}
\hline \multirow{2}{*}{ SAMPEL } & \multicolumn{2}{|c|}{ \% Rataan daya hambat Trichoderma sp } \\
\cline { 2 - 3 } & Hari 1 & Hari 2 \\
\hline Sampel 1 & $\mathbf{5 5 , 9 2}$ & 63,74 \\
\hline Sampel 2 & $\mathbf{5 3 , 7 3}$ & 71,85 \\
\hline Sampel3 & $\mathbf{5 3 , 7 3}$ & $\mathbf{5 7 , 1 8}$ \\
\hline
\end{tabular}

Tabel 1 menunjukkan Sampel 2 memperlihatkan daya hambat tertinggi yaitu $\mathbf{7 1 , 8 5 \%}$ dibandingkan sampel lainnya. Persentase penghambatan terendah 6 terdapat pada sampel 3 yaitu $\mathbf{5 7 , 1 8 \% . ~}$

\section{Jamur Patogen Colletotrichum gloesporioides Pada Tanaman Buah Baga.}

Penyebab penyakit busuk sulur pada tanaman buah naga adalah jamur Colletotrichum gloesporioides (Penz.) Ssaac. Jamur Colletotrichum gloesporioides (Penz.) Ssaac. Memiliki klasifikasi menurut Dinar (2015) sebagai berikut :

$\begin{array}{ll}\text { Kingdom } & : \text { Fungi } \\ \text { Divisio } & : \text { Mycota } \\ \text { Sub Divisio } & : \text { Deuteromycotina } \\ \text { Kelas } & : \text { Deuteromycetes } \\ \text { Ordo } & : \text { Melanconiales } \\ \text { Famii } & : \text { Melanconiaceae } \\ \text { Genus } & : \text { Collectotrichum } \\ \text { Spesies } & : \text { Collectotrichum gloesportoaide }\end{array}$

Colletotrichum gloesporioides (Penz.) Ssaac. Mempunyai miselium yang jumlahnya agak banyak, hifa bersepta tipis, mula - mula bening, putih, kemudian berwarna gelap. Konidiofor pendek, tidak bercabang, tidak bersepta dengan ukuran 7-8 x $\quad 3-4 \quad \mu \mathrm{m}$. Colletotrichum gloesporioides (Penz.) Ssaac. Colletotrichum gloesporioides (Penz.) Ssaac. Umumnya memiliki konidia hialin, bersel satu, berukuran 9-24 x 3-6 $\mu \mathrm{m}$, tidak bersekat, jorong memanjang, terbentuk pada ujung konidiofor yang sederhana. Pada saat berkecambah konidium yang bersel satu tadi membentuk sekat. Pembuluh kecambah membentuk apresorium sebelum mengadakan infeksi. Diantara konidiofor biasanya terdapat rambut rambut (seta) yang kaku dan berwarna coklat tua. Jamur Colletotricum menghasilkan konidia dalam jumlah banyak. Konidia terbentuk pada permukaan bercak pada daun terinfeksi, dan konidia tersebut mudah lepas bila ditiup angin atau bila terkena percikan air hujan. Konidia sangat ringan dan dapat menyebar serta terbawa angin sampai ratusan kilometer sehingga penyakit mampu tersebar luas dalam waktu yang singkat. Konidia kemungkinan juga disebarkan oleh serangga (Dinar, 2015). Patogen $C$. gloesporioides membutuhkan air bebas atau kelembaban relatif di atas $95 \%$ untuk perkecambahan konidia dan pembentukan appressorium. Namun, konidia dapat bertahan selama 1-2 minggu pada kelembaban terendah $62 \%$ dan kemudian berkecambah jika kelembaban $100 \%$. Secara umum, infeksi terjadi pada suhu antara 200-300 C. Diantara 200-300 $\mathrm{C}$ ada rentang diantara suhu tersebut sehingga variasi dalam suhu optimal untuk persyaratan perkecambahan dan pembentukan appressorium antara isolat $C$. gloesporioides dari lokasi yang berbeda (Arauz, 2000). Jaya (2010) melaporkan bahwa penyakit ini sudah menyerang pertanaman buah naga di Indonesia. Serangan patogen jamur yang disebabkan oleh $C$. Gloeosporioides umumnya dikenal dengan sebutan antraknosa. Penyakit antraknosa juga ditemui pada spesies buah naga kuning di Brazil. C. Gloesporioides tidak hanya menyebabkan busuk lunak batang pada $H$. undatus tetapi juga ditemukan massa konidia berwarna jingga pada buah yang terserang penyakit di Okinawa, Jepang. Penyakit ini juga dilaporkan terjadi di Florida, USA sejak Desember 2004. Di Brazil, terjadi serangan $C$. gloesporioides yang menyebabkan kehilangan sebesar 5\% pada buah naga kuning.

Gejala dimulai dari tepi sulur, bagian bercak terlihat bintik-bintik hitam yang berbaris secara teratur. Beberapa ditemui juga bercak disertai lendir, kemudian melebar dan berwarna cokelat kemerahan, hal ini sesuai dengan yang dikatakan oleh Freitas dkk. (2011) gejala yang muncul yaitu luka konsentris berwarna merah coklat yang berkembang dari halo klorotik, perkembangan pertama dekat dengan tepi sulur, khususnya ketika duri muncul dari tepi sulur. Penyakit ini kemudian muncul di bagian buah kemudian menjadi dominan selama musim hujan.

Pada umumnya C. gloesporioides merupakan jamur yang umum dan terdapat diberbagai macam tanaman sehingga sumber infeksi jamur ini dapat terjadi dengan mudah, jamur disebarkan oleh spora (konidium), dan mudah tersebar oleh percikan air hujan dan oleh aliran udara yang lembap serta dapat disebarkan oleh serangga vektor.

Infeksi dimulai dari area luka khususnya jaringan batang yang disebabkan oleh gigitan 
serangga atau infeksi sebelumnya dari antraknosa. Gejala awal yang terjadi adalah jaringan menjadi menguning diikuti dengan pelunakan dan pembusukan yang berbau dari jaringan tersebut. Infeksi lanjut menyebabkan pembusukan keseluruhan dari bagian batang yang berdaging dan sukulen pada cabang utama Luders dan McMahon (2006) Umumnya, spora cendawan disebarkan oleh angin. Bisa juga melalui peralatan pertanian, bahkan manusia. Cendawan dapat menginfeksi biji dan bertahan dalam sisa-sisa tanaman sakit.

\section{Jamur antagonis Trichoderma sp.}

Klasifikasi Trichoderma sp. menurut Alexopoulus (1979) sebagai berikut :

$\begin{array}{ll}\text { Kingdom } & \text { : Fungi } \\ \text { Kelas } & \text { : Deuteromycetes } \\ \text { Ordo } & \text { : Monilialis } \\ \text { Famii } & \text { : Moniliaceae } \\ \text { Genus } & \text { : Trichoderma } \\ \text { Spesies } & \text { :Trichoderma sp }\end{array}$

Jamur Trichoderma sp. memiliki ciri morfologi sebagai berikut: miselium bersepta, konidioforanya bercabang dengan arah yang berlawanan, konidianya berbentuk bulat atau oval dan satu sel melekat satu sama lain, wama hijau terang (Devi dkk., 2000).

Pada temperatur 25 0C dan dalam media Potato Dextro Agar (PDA) fungi ini tumbuh seperti bulu domba dan awalnya terlihat putih, selanjutnya miselium akan berubah menjadi kehijau-hijauan lalu terlihat sebagian besar berwarna hijau ada ditengah koloni dikelilingi miselium yang masih berwarna putih dan pada akhirnya seluruh medium akan berwarna hijau (Nurhayati, 2001). Setelah konidia atau tubuh buahnya terbentuk maka jamur ini 8 akan terlihat berwama hijau kebiruan. Konidia tersebut mempakan sel tunggal yang berbentuk oval yang saling melekat satu sama lain sehingga membentuk suatu kumpulan pada ujung konidiofora. Koloni fungi ini mudah dikenali dengan pertumbuhan yang cepat dan matang pada pertumbuhan 5 hari.

Konidifor dapat bercabang menyerupai piramida, yaitu pada bagian bawah cabang lateral yang berulang-ulang, sedangkan kearah ujung percabangan menjadi bertambah pendek. Fialid tampak langsing dan panjang terutama apeks dari cabang, dan berukuran $(2,8-3,2) \mu \mathrm{m} x$ $(2,5-2,8) \mu \mathrm{m}$, dan berdinding halus. Klamidospora umumnya ditemukan dalam miselia dari koloni yang sudah tua, terletak interkalar kadang terminal, umumnya bulat, berwarna hialin, dan berdinding halus (Gandjar dkk, 1999).

Pada umumnya fungi ini memiliki aroma yang khas yaitu bau kelapa dan beberapa isolat dari spesies ini dapat mengubah wama medium. Pembahan wama disebabkan oleh pigmentasi fialid yang mengeluarkan wama kuning, hijau terang dan hijau (Devi dkk, 2000).

Trichoderma $s p$. disamping sebagai organisme pengurai, dapat pula berfungsi sebagai agens hayati. Cendawan Trichoderma $s p$ merupakan mikroorganisme tanah bersifat saprofit yang secara alami menyerang cendawan patogen dan bersifat menguntungkan bagi tanaman. Cendawan Trichoderma sp. merupakan salah satu jenis cendawan yang banyak dijumpai hampir pada semua jenis tanah dan pada berbagai habitat yang merupakan salah satu jenis cendawan yang dapat dimanfaatkan sebagai agens hayati pengendali patogen tanah (Loekas dkk, 2013).

Trichoderma $s p$. dalam peranannya sebagai agens hayati bekerja berdasarkan mekanisme antagonis yang dimilikinya. Agen hayati Trichoderma $s p$. juga mampu mendekomposisi lignin, selulosa, dan kithin dari bahan organik menjadi unsur hara yang siap diserap tanaman (Wahyuno dkk., 2009).

Kemampuan masing-masing spesies Trichoderma sp. dalam mengendalikan cendawan patogen berbeda-beda, hal ini dikarenakan morfologi dan fisiologinya berbedabeda (Widyastuti, 2006). Beberapa spesies Trichoderma $s p$ telah dilaporkan sebagai agens hayati adalah $T$. harzianum, $T$. viridae, dan $T$. koningii yang tersebar luas pada berbagai tanaman budidaya (Yuniati, 2005). Beberapa hasil penelitian dilaporkan bahwa Trichoderma $s p$. dapat mengendalikan patogen pada tanaman diantaranya Rhizoctonia oryzae yang menyebabkan rebah kecambah pada tanaman padi (Semangun, 2000), Phytopthora capsici penyebab busuk pangkal batang pada tanaman lada, dan dapat menekan kehilangan hasil pada tanaman tomat akibat Fusarium oxysporum (Taufik, 2008). Dominasi Trichoderma sp. dari dalam tanah akan membuat lingkungan dan ekologi sekitar tanah menjadi lebih tahan terhadap perkembangbiakan patogen.

\section{Uji antagonis Trichoderma $s p$ Terhadap Jamur Colletotrichum gloesporioides.}

Berdasarkan data hasil pengamatan diperoleh rata-rata persentase hambatan dengan menggunakan perlakuan umur Trichoderma sp 
sampel 1 rata-rata hari pertama $55,92 \%$ dan hari kedua $63,74 \%$, sampel 2 rata-rata hari pertama $53,73 \%$ dan rata-rata hari kedua $71,85 \%$,dan

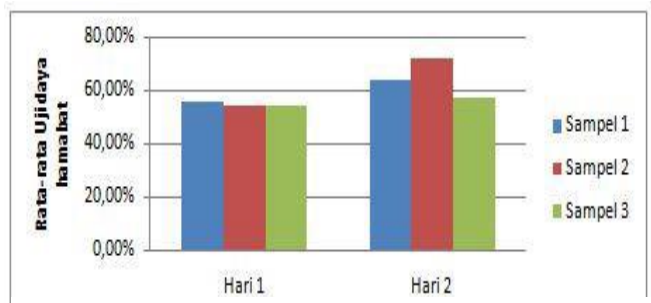

Gambar 5. Diagram rata-rata uji antagonis

Trichoderma sp terhadap jamur Colletotrichum

Adanya daya hambat tersebut menunjukkan bahwa isolat jamur Trichoderma $s p$ memiliki sifat antagonis terhadap jamur Colletotrichum gloesporioides. Hal ini ditandai dengan terjadinya mekanisme penghambatan berupa dikeluarkannya senyawa antibiosis dan hiperparasit yang dapat diamati dengan terbentuknya zona bening sebagai zona penghambatan pertumbuhan bagi Colletotrichum gloesporioides dan pertumbuhan hifa Trichoderma $s p$ yang lebih cepat sehingga mendesak pertumbuhan Colletotrichum gloesporioides (Gambar 6).

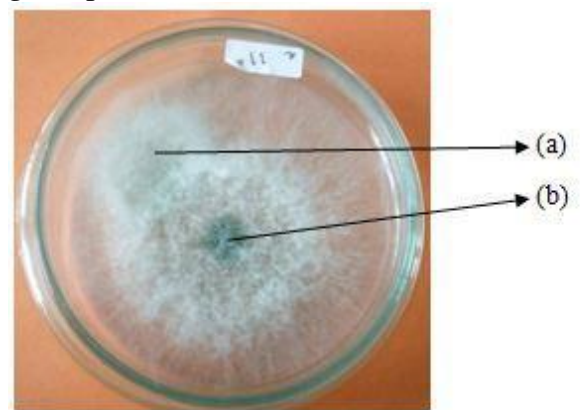

Gambar 6. Jamur Trichoderma sp menghambat pertumbuhan Colletotrichum gloesporioides (a) Colletotrichum gloesporioides (b) Trichoderma $s p$

Jamur Trichoderma sp mempunyai kemampuan sebagai parasit dan bersifat antibiosis karena menghasilkan enzim yang secara aktif mendegradasi sel-sel patogen, sehingga menyebabkan lisisnya sel-sel kapang patogen dan mengeluarkan trikotoksin yang dapat mematikan kapang patogen (Liswarni dkk., 2007). Mukarlina dkk., (2011) mengatakan bahwa mekanisme antibiosis dapat terjadi karena adanya metabolit sekunder yang diproduksi oleh mikroba yang secara alamiah merupakan suatu mekanisme pertahanan mikroba untuk bertahan hidup atau berkompetisi. Octriana (2011) menyatakan bahwa Trichoderma $s p$ menekan patogen dengan empat mekanisme, yaitu dapat sampel 3 rata-rata hari pertama $53,73 \%$ dan ratarata hari kedua 57,18\%. Seperti gambar 4.

menghasilkan khitinase, $\beta$ 1,3-glukanase, mikoparasit dan kompetisi penggunaan nitrogen dan karbon.

Arya dan Perello (2010), Trichoderma sp. mampu mengeluarkan senyawa antibiotik seperti gliotoksin dan glioviridin. Pernyataan ini dipertegas oleh Vey dkk., (2001), yang menyatakan bahwa Senyawa antibiotik tersebut mempengaruhi dan menghambat banyak sistem fungsional dan membuat patogen rentan. 10 Trichoderma $s p$ juga bersifat toleran terhadap stres dan mampu menginaktifkan enzim mikroba patogen. Selain itu, Trichoderma sp. Mampu menghasilkan enzim penghidrolisis dinding sel patogen yang akan menghambat sintesis dinding sel patogen dan meningkatkan keaktifan yang bersifat fungisida, akibatnya jamur patogen mengalami penurunan kecepatan pertumbuhan (Harman 2000).

\section{KESIMPULAN}

1.Patogen penyebab penyakit busuk sulur pada tanaman buah nagadi Desa Bukit Merdeka, Kecamatan Samboja, Kabupaten Kutai Kartanegara adalah jamur Colletotrichum gloesporioides (Penz.) Ssaac.

2.Trichoderma sp dapat menghambat perkembangan patogen Colletotrichum gloesporioides (Penz.) Ssaac., dengan hambatan rata-rata tertinggi sebesar 71,85\%.

\section{DAFTAR PUSTAKA}

Agrios, G. N. 1996. Ilmu Penyakit Tumbuhan. Gadjah Mada University Press. Yogyakarta.

Alexopoulos, C.J. Dan Mimms, C.W. 1979. Introductory Mycology. John Wiley \& Sons. New York.

Andipati. 2004. Buah Naga. Http://Andipati.Wordpress.Com

Andoko A, Nurrasyid H. 2012. Jurus Sukses Hasilkan Buah Naga Kualitas Prima. Solo: Agromedia.

Arauz Lf. 2000. Mango Anthracnose. Economic Impact And Current Options For Integrated Management. Plant Dis. 84 (6).

Arwiyanto T. 2003. Pengendalian Hayati Penyakit Layu Bakteri Tembakau. Jurnal 
Perlindungan Tanaman Indonesia 3(1): 5460.

Arya, A And A. E. Perello. 2010. Management of Fungal Plant Pathogen. Publised By Cab International. London.

Bellec FL, Vaillant F, Imbert E. 2006. Pitahaya (Hylocereusspp.): A new crop, a market with future. Fruits 61: 237-250. 11 Cahyono B. 2009. Buku Terlengkap Sukses Bertanam Buah Naga. Jakarta :Pustaka Mina.

Devi, S. Nugroho, T.T., Chainulfiffah, Dahliaty, A. 2000. Pemumian enzim selulase ekstra seluler dari jamur Trichoderma viride TNJ63 isolat dari wilayah daratan Riau. Laporan penelitian Pekanbaru: Lembaga Penelitian Universitas Riau.

Dinas Pertanian Tanaman Pangan Kaltim. 2009. Laporan Tahunan. Dinas Pertanan Tanaman Pangan Kaltim, Samarinda.

Dinas Pertanian Tanaman Pangan Kaltim. 2014. Laporan Tahunan. Dinas Pertanan Tanaman Pangan Kaltim, Samarinda.

Dinar, N, A. 2015. Penyakit Antraknosa (Colletotrichum gloeosporioides (Penz.) Sacc.) Pada Pembibitan Tanaman Kakao (Theobroma Cacao L.). Fakultas Pertanian. Universitas Muhammadiyah Malang. Malang

Domsch, K.H., Gams, W., Anderson, T.H. 1980. Compendium of soil fungi. Vol 1

Academic press, London.

Eng, L. 2012. Disease Management Of Pitaya. Department of Agriculture Sarawak. [Diunduh 2016 Agustus 20]. Tersedia Pada: Http://Www.Doa.

Sarawak.Gov.My/Modules/Web/Page.Php?I $d=454$.

Escribano, J., Pedreño, M.A.,Garcia-Carmona, F. \& Muñoz,R. 1998. Characterization of The Ntiradical Activity of Betalains from Beta Vulgaris L. Roots. Phytochemical Analysis 9: 124-127.

Evans Hc, Holmes Ka, \& Thomas Se. 2003. Endophytes And Mycoparasites Associated With an Indigenous Forest Tree, Theobroma gileri, In Ecuador And A Preliminary Assessment of Their Potential As Biocontrol Agents Of Cocoa Diseases. Mycological Progress 2: 149-160.
Food And Agriculture Organization. 2012. Fruit Of Vietnam. Fao Corporate Document Repository. [Diunduh 2016 Juli 26). Tersedia Pada: Http://Www.Fao.Org/Docrep/008/Ad523e/A d523e05.Htm

Freitas Std, Nham Nt, Mitcham Je. 2011. Pitaya (Pitahaya, Dragon Fruit) Recommendations For Maintaining Postharvest Quality. Department Of Plant Sciences, University Of California.

Gandjar, I., Robert A.S., Karin V.D., Ariyanti O., Dan Iman S., 1999. Pengenalan Kapang Tropik Umum. Yayasan Obor Indonesia. Jakarta.

Harman, G.E., C. R. Howell., A. Viterbo., I. Chet., And M. Lorito. 2000. Review: Trichoderma Species-Opportunistic, Avirulent Plant Symbionts. Departments Of Horticultural Sciences And Plant Pathology. Cornell University. Usa.

Http://Kaltim.Prokal.Co/Read/News/254498Waduh-Gawat-Perkebunan-Buah-NagaDiserang-Jamur. Diakses 28 Juli 201612 Http://Www.Kutaikartanegaranews.Com/20 16/07/436-Hektar-Lahan-Tanaman-BuahNaga-Di-Samboja-Terserang-Penyakit.Html

Ictira, J. 2015. Cara Membuat Media PDA. Sekolah Tinggi Penyuluhan Pertanian. Yogyakarta.

Jaya, I. K. D. 2009. Studi Pe Ndahuluan Tentang Praktek Budidaya Dan Potensi Pengembangan Tanaman Buah Naga (Hylocereus Spp.) Di Kabupaten Lombok Utara. Seminar Nasional "Kebijakan Dan Penelitian Di Bidang Pertanian Untuk Pencapaian Kebutuhan Pangan Dan Agroindustri”. Fakultas Pertanian Unram, 14 Maret 2009.

Jaya Ikd. 2010. Morphology And Physiology of Pitahaya And It Future Prospects In Indonesia. Crop Agro. 3:44-50.

Jumjunidang, Riska Dan I. Muas. 2012. Outbreak Penyakit Busuk Batang Tanaman Buah Naga di Sumatera Barat. Laporan Hasil Survey Opt di Sentra Produksi Buah Naga Sumatera Barat. Balitbu Tropika Solok. 
Kristanto, D. 2003. Buah Naga Pembudidayaan di Pot dan di Kebun. Penebar Swadaya. Jakarta.

Kurniawan, D. 2008. Mengenal Buah Naga (Dragon Fruit). Http://Dkbreakthrough.Blogspot.Com.

Kristanto D. 2009. BuahNaga :Pembudidayaan di Pot dan di Kebun. Jakarta: PenebarSwadaya.

Lemke, C. 2007. Hylocereus Undatus NightBlooming Cereus Cactaceae. University of Oklahoma Department of Botany \& Microbiology.

Lichtenzveig, J. Et. Al. 2000. Cytology And Mating Systems In The Climbing Cacti Hylocereusand Selenicereus. American Journal of Botany. 87: 1058-1065.

Liswarni, Y., F. Rifai \& Fitriani. (2007). Efektivitas Beberapa Spesies Trichoderma Untuk Mengendalikan Penyakit Layu Pada Tomat, yang Disebabkan Oleh Fusarium oxysporum. J. Litbang Pertanian (1) : 39-42.

Loekas, S. Endang, M. Ruth, F, R. Ratna, S ,D. 2013. Uji Kesesuaian Empat Isolat Trichoderma Spp. Dan Daya Hambat In Vitro Terhadap Beberapa Patogen Tanaman. J. Hpt Tropika. Fakultas Pertanian Dan Fakultas Biologi, Universitas Jenderal Soedirman. Purwokerto.

Luders L, McMahon G. 2006.The Pitaya or Dragon Fruit (Hylocereus undatus). Agnote Northern Territory Government. No D42.

Marhazlina, M. 2008. Departement of Nutrition And Dietetic Faculty of Medicine And Health Sciences. University Putra, Malaysia.

McMahon G. 2003. Pitaya (Dragon Fruit).Northern Territory Government. FF12: 1-2. (FF12pitaya) 13 Merten S. 2003. A Review Of Hylocereus Production In The United States. Journal Pacd [Internet]. 5:98105. [Diunduh 2011 April 22]. Tersedia Pada:

Http://Www.Jpacd.Org/Downloads/Vol5/V5 p98-105.Pdf

Mukarlina, Siti Khotimah \& Laily Febrianti. (2011). Uji Antagonis Trichoderma harzianum Terhadap Erwinia Sp., Penyebab Penyakit Busuk Bakteri Pada Aloe Vera. J. Fitomedika (3) : 150-154.
Masyahit M, Sijam K, Awang Y, Ghazali M, Satar M. 2009. The first report of the occurrence of anthracnose disease caused by Colletotrichum gloeosporioides(Penz.) Penz. \&Sacc. on dragon fruit (Hylocereus spp.) in Peninsular Malaysia. American Journal of Applied Sciences. 6 (5): 902-912.

Nurhayati, H., 2001. Pengaruh Pemberian Trichoderma Sp. Terhadap Daya Infeksi Dan Ketahanan Hidup Sclerotium roflsii Pada Akar Bibit Cabai. Skripsi Fakultas Pertanian Untad, Palu

Octriana, L. (2011). Potensi Agen Hayati Dalam Menghambat Pertumbuhan Phytium Sp Secara In Vitro. Buletin Plasma Nutfah (17) : 138-142

Palungkun, R Dan Indrayani. 1992. Hama Dan Penyakit Sayur Dan Palawija. Ed Ke-1. Penebar Swadaya. Jakarta.

Purwantisari, S. 2009. Isolasi Dan Identifikasi Cendawan Indigenous Rhizosfer Tanaman Kentang Dari Lahan Pertanian Kentang Organik Di Desa Pakis. Magelang. Jurnal Bioma. Issn: 11 (2): 45.

Pushpakumara DKNG, Gunasena HPM, Karyawasam M. 2005.Flowering and fruiting phenology, pollination vector and breeding system of dragon fruit (Hylocereus spp.).Sri Lankan J. Agric. Sci. 42:81-91.

Renasari N. 2010. Budidayatanamanbuahnaga super red di WanaBektiHandayani [skripsi]. Purwokerto: FakultasPertanian, Universitas Sebelas Maret.

Semangun, H. 2000. Ilmu Penyakit Tumbuhan. Gadjah Mada University Press, Yogyakarta.

Setyowati, A. 2008. Analisis Morfologi Dan Sitologi Tanaman Buah Naga Kulit Kuning (Selenicereus megalanthus). Fakultas Pertanian Universitas Sebelas Maret. Surakarta.

The Sarasota Fruit \& Nut Society. 2010. Pitaya Diseases. [Internet]. [Diunduh 2016 Oktober 08] Tersedia Pada: Http://Www. Sarasotafruitandnutsociety.Org/Information/ Tropicalfruit/Dragonfruitdiseases.Html.

Sudarmini, S. D. 2005. Penyuluhan Budidaya Buah Naga (Dragon Fruit) Dan Penyuluhan 
Pembibitan Dragon Fruit. Politeknik Lpp Yogyakarta.

Sudantha, I, M, Kesratarta I, Sudana. 2011. Uji Antagonisme Beberapa Jenis Jamur Saprofit Terhadap Fusarium Oxysporum F. Sp. Cubense Penyebab Penyakit Layu Pada Tanaman Pisang Serta Potensinya Sebagai Agens Pengurai Serasah. Unram, Ntb. Jurnal Agroteksos 21 (2): 2-3.

Sumadi, B. 2013. Untung berlipat dari budidaya buah naga organik. Edisi Ke-1. Yogyakarta: Lily Publisher.

Supriati, L., R. B. Mulyani. Dan Y. Lambang. 2010. Kemampuan Antagonisme Beberapa Isolat Trichoderma Sp., Indigenous Terhadap Sclerotium rolfsii Secara In Vitro. J. Agroscientic. 17(3): 119-122.

Sutomo, Budi. 2007. Buah Naga Merah - Segar Dan Berkhasiat.Http://Myhobbyblogs.Com

Suwahyono, U. 2009. Biopestisida. Pt. Niaga Swadaya. Jakarta.

Taufik, M. 2008. Efektivitas Agens Antagonis Trichoderma Sp. Pada Berbagai Media Tumbuh Terhadap Penyakit Layu Tanaman Tomat. Prosiding Seminar Ilmiah Dan Pertemuan Tahunan Pei Pfi Xix Komisariat Sulawesi Selatan. Makassar.

Vey, A., R. E. Hoagland Dan T. M. Butt. 2001. Fungi As Biocontrol Agents: Progress Problems And Potential. In Butt, T. M., C. Jackson And N. Magan (Ed). Toxic Metabolite of Fungal Biocontrol Agents. Publishing Cab International. London.

Warren, Levinson. 2008. Review of Medical Microbiology \& Immunology Tenth Edition. The Mcgraw-Hill Companies, Inc. New York.

Wahyu. 2008. Buah Naga (Dragon Fruit). Http://Antiterasi.Multiply.Com

Wahyuno D, Manohara D, Dan Mulya K. 2009. Peranan Bahan Organik Pada Pertumbuhan Dan Daya Antagonisme Trichoderma Harzianum Dan Pengaruhnya Terhadap $P$. Capsici. Pada Tanaman Lada. Jurnal Fitopatologi Indonesia 7: 76-82.

Weiss, J.,Nerd, A. And Mizrahi, Y. 1994. Flowering Behavior And Pollination
Requirements In Climbing Cacti With Fruit Crop Potential. Hort Science. 29 (12):14871492.

Widiastuti, L., Tohari Dan Sulistyaningsih, E. 2005. Pengaruh Intensitas Cahaya Dan Kadar Dominsida Terhadap Pembungaan Dan Kualitas Tanaman Krisan Dalam Pot. Jurnal Grosains. 18 (3) : 315-326.

Widyastuti Sm, Sumardi, Irfa Dan Harjono, 2006. Aktivitas Penghambatan Trichoderma Spp. Terformulasi Terhadap Jamur Patogen Tular Tanah Secara In-Vitro. Jurnal Perlindungan Tanaman Indonesia 8: 27-39. 15 Yuniati. 2005. Pengaruh Pemberian Beberapa Spesies Trichoderma Sp. Dan Pupuk Kandang Kambing Terhadap Penyakit Layu Fusarium oxysporum F. Sp Lycopersici Pada Tanaman Tomat (Lycopersicum esculentum Mill) [Skripsi] Jurusan Budidaya Pertanian, Fakultas Pertanian, Universitas Muhammadiyah. Malang. 
